\title{
国際電気化学会議の開催に当たって
}

\author{
杉 野 喜 一 郎*
}

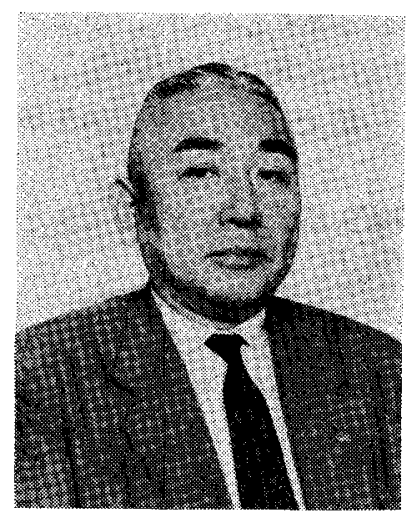

第 17 回国際電気化学会議 (17 th Meeting of CITCE) もあと旬日 の後に迫りました.

この会議についての国内組織委員会は昨年 6 月 12 日結成されて以来 今日まで数回開催され，会の運営方針，必要な募金計画などが協議され かつ実行に移されてまいりました，その間 2 3 人の委員からなる専門 分野の分科会も並行して開かれ，主として特別講演者の選定とプログラ 厶編成の仕事を担当されました. 特に後者は 3 月 1 日論文締め切り後は 多忙をきわめ最近やっと最終プログラムも決定され開会を待つばかりに なりました。ここまで万事が順調に運びましたのは組織委員会，分科会 の委員各位の絶大な奉仕精神と田島事務局長の超人的努力のたまもので あり，各位のご尽力に対し東心より深謝いたします。この間本協会は主 スポンサーとして会をあげて応援され，募金および経理事務をお引き受けいただいたことはどれだけ会 務運営を円滑にしたか計り知れません．日本化学会も同会として異例の金一封を会よりきょ（拠）出さ れ，スポンサーの一つとして応援されており，日本学術会議も同じくスポンサーに名をつらねていただ きました．以上の三学術団体のご厚意に対してもここにつつしんで謝意を表します．また本会会員のみ なさまには今日までのご協力にお礼申し上げますとともにたとえ論文を発表されない方でも多数会議に ご参加いただき会をいっそう盛大なものとしていただきたくお願いいたします．

プログラム (案) によりますと発表論文数は 176 に及゙，ほかに特別講演 22 を含め予定された会期 と会場でほんとうに一杯という盛況でありましてご同慶にたえません．また，諸外国よりの来会者（正 式登録者）も家族を入れて約 166 名に及び，論文数も 96 に達し，全論文の $55 \%$ を占めております。 欧州あるいは米州のかたがたから見れば従来の開催地に比べ格段に遠方で旅費が大変と思われる東京人 かくも多数出席して平素の研究結果をひろらしてもらえることは何といってもうれしいことであり，わ が国の電気化学界にとって画期的のできごとといえましょう．ただ招待講演者に旅費を出すことを差し 控えたため一部参加不能になった著名なかたがたがあり，残念至極でございます．しかし学会の良さは 参加者が皆平等の立場で学的人的に交流する所にあることを考えますと，18人に及ぶ外国特別講演者を 区別することもいかがかと思われやむをえず上記のような措置をとりました．ど5か参加を予定されて いる諸外国よりの来会者全員が予定ど扔り来日され，元気な姿を会場に見せていただけることを心から 新念いたします.

講演発表論文の詳細については田島教授の紹介にまつこととして，全体のすうせいだけを見ますと， 一般課題 I と腐食部会 (5) の合同集会に 6 件の特別講演と 36 件の発表論文，一般課題 II と有機電気 化学部会 (8) の合同集会に 5 件の特別講演と 31 件の論文発表が予定されており，この二つが今回の中 心課題であることを物語っております．ほかの部会で多いのは電池部会の 34 件，反応速度論部会の 29 件拉よび高温電気化学部会の 16 件であり，一般電極反応論に関する論文が多いのは当然ですが，電池 と溶融塩の二つは京都における討論会の課題でもあり，やはり今回の特色の一つでありましょう．また 主催国で当然かも知れませんが，わが国のかたがたの発表論文数は全体の約 $45 \%$ に当たる 80 件を数 え，日頃のうんちくを傾けていただけることは慶賀にたえません。

* CITCE 国内組綃委員会委員辰, 東京工業大学（東京都目黑区大岡山） 
さらに京都部会（溶融塩拄よび然料電池に関する討論会）は吉沢委員を始めとする関西在住委員各位 のご努力で着々準備が進められ，これまた，プログラムも完成し，開会を待つばかりになっていると同 って抲ります．これについては吉沢教授の紹介文をご覧願います。

最後にこの会議運営上の資金でありますが，これは参加者からの会費だけではとうていまかないきれ ません．そこで組織委員会では全委員が募金委員として募金に当たり，諸団体諸会社にご依頼いたしま したところ，予期以上のご協力が得られ，どうやら最初の目標額に達することができましたことご同慶 の至りと存じます．この機を拝借しご賛同を得ました各社各団体に謝意を表わしますとともに，委員各 位のご努力には満こう（腔）の敬意を表する次第でございます．特に本協会では水野副会長が率先して これに当たり，ご多忙中を東奔西走していただいたことは感謝にたえません，紙上を借りて厚く扔礼申 し上げます。

どうか「次はミュンヘンで会いましょう」の合言葉でお別れするまで円満盛大に会が運びますことを 新って筆を抢きます.

\section{CITCE の成立と発展について}

田島栄*

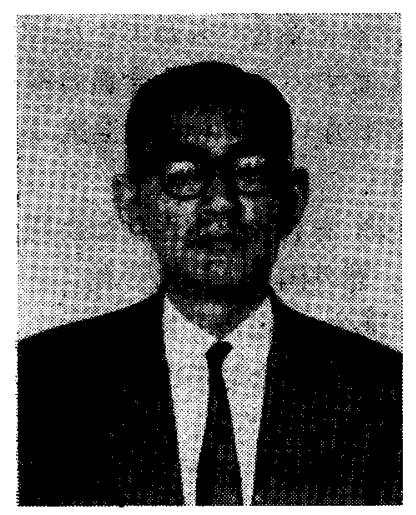

1948 年 9 月に Faraday Society の Process Metallurgy シンポジウ ムに出席の車中で, M. Pourbaix と Van Rysselberghe（来日予定）の 両氏の間で電気化学熱力学とその応用（特に Corrosion）への論議がな され,一つの協力的な委員会を設けることが発案されこれを数名の同志 に提示した。 その中には G. Valensi (来日予定)，P. Piontelli，T.P. Hoar, J. O'M Bockris や J. Heyrovsky があった.

第 1 回の会合は 1949 年 4 月 Bruxelles で行なわれ，共同研究テー マとして，(1) $25^{\circ} \mathrm{C}$ の水溶液における金属および非金属の電気化学的 挙動,（a）電気化学平衡図，（b）電極反応論, 特に 分極曲線の確立,

（2）これらの金属腐食への応用，（3）一般化学，分析化学への応用， （4）電解現象, 電析, 電解研摩, 電池, 蓄電池への応用が選ばれた。 そ して初代会長は P. Van Ryssellerghe, 副会長 A. Julliard, 事務局長 M. Pourbaix で,メンバーは 1950 年には 40 名, 14 力国にすぎなかった. 当時ソ連の Akimov にも勧誘状を送ったが返信はなかったと いう.またチェコの Heyrovsky もビザがおりず参加不能であったという. 第 2 回は Piontelli の世話で Milano で開かれ “電気化学命名法拉よび定義”の委員会も発足した”。当時の論文集をみるとたとえば Corrosion の部門で, 各金属の電気化学的挙動, 不動態などについて各人が分担研究をしていることが わかる，その後この委員会は逐年発展し, Bern (1951), Cambridge (1952), Stockholm (1953), Poitiers (1954), Lindau (1955), Madrid (1956), Paris (1957), Amsterdam (1958), Wien (1959), Bruxelles (1961), Roma (1962), Moscow (1963), London-Cambridge (1964), Budapest (1965), を経てついに Tokyo-Kyoto（1966）となったしだいである. 1953 年 IUPAC の Stockholm 会議で CITCE 命名法 委員会の電極電位の符号に関する提案が採択され, これは Stockholm Convention として広く知られて いると抢りである。

このとき以来 CITCE は IUPAC の Affiliated Commission として承認されたが, 会合上も, 財政

* National Secretary for Japan, CITCE, 同国内組䋘委員会事務局長, 東京都立大学工学部 (東京都世田谷区深沢町) 